\title{
BUILDING AN ONLINE COMMUNITY: STUDENT TEACHERS' PERCEPTIONS ON THE ADVANTAGES OF USING SOCIAL NETWORKING SERVICES IN A TEACHER EDUCATION PROGRAM
}

\author{
Akhmad HABIBI \\ Jambi University, Indonesia \\ Amirul MUKMININ \\ Jambi University, Indonesia \\ Dr. Yatim RIYANTO \\ Surabaya State University, Indonesia \\ Lantip Diat PRASOJO \\ Yogyakarta State University, Indonesia \\ Urip SULISTIYO \\ Jambi University, Indonesia \\ Muhammad SOFWAN \\ Jambi University, Indonesia \\ Ferdiaz SAUDAGAR \\ Jambi University, Indonesia
}

\section{ABSTRACT}

This inquiry examined student teachers' perceptions on the advantages of using Social Networking Services (SNS) in an English teacher education program at a public university in Jambi, Indonesia to ease the communication, supervision, discussion, and report submissions between supervisors and student teachers. The networking types included in the program are Whatsapp, Telegram, Email, and Google Form. The method of the research was qualitative through using focus group discussions as the technique of collecting data involving forty-two student teachers. We organized our analysis and discussion around their perceptions and the contexts in which the advantages they perceived emerge. The analyses of the texts revealed that two salient themes with their sub-themes related to the advantages of using Social Networking Services (SNS) in a teacher education program were social interaction (peer discussion and platform to interact with supervisors or lecturers) and learning motivation and experience supports (self-directed learning, promotes critical thinking, content engagement). Some pedagogical and social implications are also discussed.

Keywords: Student teachers, social networking services, teacher education.

\section{INTRODUCTION}

Technology provides resources and opportunities of new eases, applications, approaches, and strategies in education. The success of any initiatives in implementing technology in an educational program depends on the supports and attitudes of the involved users. Improvement in education is compulsory and the advancement of technology which currently shows a significant contribution to all aspects of life has proved to influence the 
shift on how education perceived, implemented, evaluated, and proposed (Isman \& Dabaj, 2004). It is necessary that the use of technologies should be implemented in education. Furthermore, the importance of the use of technology in the training of teaching for student teachers has also been significantly conducted and published in the past few years (Shirvani, 2014).

One of the utilized technologies implemented in education is Social Networking Services (SNS). The establishment and well-popularity of social applications in the last decades have encouraged some lecturers or educators or teachers to use these technologies for education processes at the university level. Furthermore, SNS in educational activities is defined as the use of appropriate technologies to facilitate a range of teaching and learning activities in collaborative settings. Boyd (2007) stated that Social Networking Services was a mediated public signed by four properties: searchability, persistence, replicability, and invisible audiences. SNS focuses on the technologies which are commonly called tools of social networking and widely applied to include a range of social technologies such as Whatsapp, Telegram, Edmodo, Google Form, Facebook, Twitter, Youtube, etc. These media facilitate collaborative and interactive learning which is important in education.

Collaborative learning such as learning how to solve problems in groups is one of the uses of SNS (Hemmi, Bayne, \& Land, 2009; Kane \& Fichman, 2009). Many researchers have discussed the broad learning advantages of using social technologies in higher education (McLoughlin \& Lee, 2008; Schroeder, Minocha, \& Schneider, 2010) and there have been many published case studies of successful implementations of SNS activities in higher education (Hosny \& Fatima, 2012; Irwin, Ball, Desbrow, \& Leveritt, 2012; Lee, 2014; Pursel \& Xie, 2014) in which students' perspectives are significantly suggested in the evaluations of specific SNS activities (Amador \& Amador, 2014). In addition, although SNS improves collaborative learning and increases interactions among students and teachers or lecturers, to our knowledge, research on students' feelings on its advantages is comparatively rare in Indonesia. Additionally, studies that have revealed SNS interactions tend to focus on the forms of the interactions, rather than users' perceptions (Kuo, Walker, Schroder, \& Belland, 2014). Students' perceptions are important to see the sustainability of the program and to establish future SNS implementation.

This inquiry was intended to examine student teachers' perceptions on the advantages of using Social Networking Services (SNS) in an English teacher education program at a public university in Jambi, Indonesia to ease the communication, supervision, discussion, and report submissions between supervisors and student teachers. The networking types included in the program are Whatsapp, Telegram, Email, and Google Form. To achieve the purpose of this study, one major research question guided us: What are student teachers' perceptions on the advantages of using Social Networking Services (SNS) in an English teacher education program in Jambi, Indonesia to ease the communication, supervision, discussion, and report submissions between supervisors and student teachers?

\section{LITERATURE REVIEW}

\section{Social Networking Services}

Social networking services used by world citizens which are available for free, are popular nowadays (Brown, 2010; Hamid, Waycott, Kurnia, \& Chang, 2014). Social technologies are able to make flexible supporting in the process of teaching and learning and in the ease of public publication, to provide the sharing of ideas and re-utilizing of study content, and commentaries. They also provide links for supporting resources of relevant information controlled by the users, students, and teaching staff (Brown, 2010; Kaplan \& Haenlein, 2010). Those factors have made higher education increasingly utilize them in the process of teaching and learning (Brown, 2010; Schroeder et al., 2010; Habibi, 2015). SNS can also be differentiated from social activities that are offline (i.e., face-to-face). In the literature, the terms of social media and social technologies are often used 
interchangeably. Lowedahl (2011) describes social media as web environments where content is aggregated, performed, and distributed. Social technologies can be utilized to support teaching and learning through SNS educational activities in higher education. Some instances of SNS educational activities are content sharing, interacting, and collaborating (Osman \& Koh, 2013; Sandars \& Schroter, 2007). Students are able to publish their work publicly for others to watch, listen, and download. For instance, multimedia files can be shared on file sharing Services such as Flickr, YouTube or Slideshare, and social bookmarking Services which allow users to bookmark certain webServicess (Lockyer \& Patterson, 2008). Social technologies also support interactions by engaging students to actively participate in a talk. They can fill in comments on a blog discussion forum and inquiry for more detailed information, add friends and initiate communication by messaging (McLoughlin \& Lee, 2007).

\section{Advantages of Social Technologies in Higher Education Teaching and Learning}

The existing literature suggests some advantages of the online social networking for educational purposes. The issues bring the use to increasing students' communication and interaction (Crook et al., 2008; Odom, 2010), supporting learning motivation and experience, and providing personalized course materials (Chen et al., 2011; Hosny \& Fatima, 2012). Some researchers argue that SNS in educational activities are valuable for developing students' collaborative skills because social technologies appeal to them (Ellison, 2007; Hall \& Hall, 2010; Tay \& Allen, 2011). The use of SNS has contributed to higher score in some direct instances and increase the efficiency and mastery of task (Pursel \& Xie, 2014). All in all, SNS can improve students' participation. Less active students can get more benefits from SNS. Through the use of social technologies, they may reduce anxiety levels.

In addition, Hamid et al. (2015) reported that the benefits of online system services use in their study involved Australian and Malaysian higher students which include studentstudent interactions, student-teacher interactions, and student-content interactions. Preece and Shneiderman (2009) revealed that students would be more active in producing their knowledge through the use of social technologies because they had a space to expose and explore themselves to publish their work online. A study conducted by Rifkin et al. (2009) showed that students' works would be more original, thoughtprovoking, and engaging for other people to understand when they publish it. However, Hamid et al. (2011) argued that some considerations were revealed by the students regarding the limitations of SNS use were lack of technological skills, time management, and limited technical infrastructures in some schools. In addition, Waycott et al. (2013) mentioned that students' works were likely be more visible to others when using social technologies in higher education which could be motivating, but also presented challenges such as the fear of students that other students would copy their work and the need for lecturers to educate the students for being careful when presenting their work in an online environment.

\section{Evaluations of Social Technologies in Specific Learning Settings}

The use of specific social technologies in particular discipline settings in various regions has been examined by a number of researchers. Firstly, Alam (2008) explored the use of wikis and blogs across three universities in Australia for increasing student engagement and interaction. The findings indicated that students' feedback based on their experiences of using these social technologies included positive experiences in their interactions with the lecturers through blogs and comments (Alam, 2008). Additionally, Zeeng et al. (2009) reported that Flickr, a photo sharing technology, had successfully implemented in a firstyear photography subject within a design education program in one Australian university. This success was later expanded to create a dynamic, global classroom, introducing students to international perspectives, and to partnerships with another university in Australia and in the United States.

Moreover, a study conducted by Yu, Tian, Vogel, and Kwok (2010) reported that online discussions between students through social learning communities such as mobile 
learning communities improved students' social connections and their self-esteem, and boosted their learning performance. Preston and his colleagues (2010) found that nearly $70 \%$ of students stated that they learned just as well in online learning communities such as WhatsApp groups, Facebook communities, Twitter chats and Google+ communities, as they did in lectures that were held in the classroom in the presence of other students. Also, Cloete, de Villiers, and Roodt (2009) who identified that some course contents were not conducive to online networking. However, some courses could potentially benefit from using SNS such as in disciplines of language, the arts, social sciences, business, ICT, and management (Hemmi et al., 2009). Research also shows that students tend to separate life from studying and home from lectures (Wang, Woo, Quek, Yang, \& Liu, 2012) which is consistent with the earlier findings by Jones et al. (2010) on students' discomfort in mixing learning with social lives on social technologies. In the meantime, Waycott et al. (2010) argued that the integration of technologies should be done by the lecturers in their teaching only if and when they saw educational values in doing it. Therefore, before SNS is adopted in higher education, a thorough evaluation need to be conducted to assess its appropriateness for teaching and learning.

\section{METHODOLOGY}

For this study, a qualitative design in the case study tradition was used to examone student teachers' perceptions on the advantages of using Social Networking Services (SNS) in an English teacher education program in Jambi, Indonesia to ease the communication, supervision, discussion, and report submissions between supervisors and student teachers. The networking types included in the program are Whatsapp, Telegram, Email, and Google Form. For our study, we were influenced by the work of one methodologist in the area of case study research, Merriam (1998) who defined a case study as "an intensive, holistic description and analysis of a bounded phenomenon such as a program, an institution, a person, a process, or a social unit" (p.xiii). She (1998) further argued that an exploratory case study was suitable when the focus of the investigation has not been examined exhaustively as is the case with student teachers' perceptions on the advantages of using SNS. For sampling, Creswell (2007) wrote that the concept of purposeful sampling is used in a qualitative study. It means that the inquirers select participants for their study because their participants can purposefully inform an understanding of the research issues. We used a purposeful sampling with a convenience case strategy. Creswell (2007) wrote, "convenience cases, which represent sites or individuals from which researchers can access and easily collect data" (p. 126). We utilized this strategy in choosing the research sites and participants because we had access to do research and collect data at the sites.

We did our study at an English teacher education program, a public university Jambi, the southern part of the Sumatra Island, Indonesia that has more than $\mathbf{5 0 0}$ student teacher from the first year to the fourth year. During their fourth year, all of student teachers are required to do teaching practicum at their designated schools. In this study, of eighty-six participants who were previously and officially invited by letter, a total of fourty-two student teachers were voluntarly involved in this study. The research took a-12 month time to finish. Given the fact that Social Networking Services (SNS) in higher education has become a truly global phenomenon, it is valuable to take a broad view and consider the views of users. The student teachers as the users had done their teaching practicum in four junior high schools with a regular supervision, communication, discussion, and report submission from/to the two supervisors and peers with the use of SNS for a 6month period. The supervisors used SNS (Whatsapp, Telegram, Google Form, and Email) which had been informed and explained to us before the research was conducted. Focus groups were widely applied in academia world in research on attitudes, feelings, experiences, and reactions in a way that would not be achievable with one to one interviews, questionnaires, and observations. The environment of focus groups lets participants participate, react, and establish upon responses of other members or think with synergy in a group setting' (Klein, Tellefsen, \& Herskovitz, 2007; Mukminin, 2012a). 
As a result, focus group discussion is considerably suggested as the most appropriate method in this study.

A total of four focus group discussion sessions were conducted when the program was completed. The two program supervisors who respectively supervised twenty-one student teachers and implemented the use of SNS in the program were asked to discuss with the researchers on the topics given. They participated in the focus groups with a request from the supervisors to attend the group discussion as a part of final sharing with comments, reflections, and suggestions. The existence of the possibility of bias in which prospective student teachers who did not enjoy SNS would be more persistent, the request was made and prior-informed before the program to invite the volunteers in the program in the cooperation with program administration.

The focus groups took around $\mathbf{6 0}$ to $\mathbf{7 5}$ minutes each defending on the development of the topics and delivered in Indonesian to get best understanding of what the participants revealed during the discussions. The first and second authors provided and facilitated all the focus group sessions by addressing to the pre-prepared focus group discussion protocol. We asked some questions and focused on three main topics: their personal and educational use of SNS; the activities and experience of SNS use in the program (specifically focusing on interaction with both lecturers and colleagues); and the outcomes which included the benefits of SNS use.

The sessions were held in one public university teacher education program. Every student teacher in each focus group completed a form giving their permission to participate in this study. The video-tapings of the focus group discussions were available and the audios were transcribed manually. For anonymity purposes, the participants were identified using their focus group number and the order of seating in the focus group discussion. Mack, Woodsong, Macqueen, Guest, \& Namey, (2005) stated that the dignity of all participants in research had to be appreciated and this principle encompassed that people would not be used simply as a tool to obtain research objectives. The demographic information of the research participants in the focus groups is pictured in Table 1. Participants in each focus group were represented by a code to protect their identity. For example, the code FG1M1 was used to represent male student 1 from group discussion 1, FG4F25 for group No. 4 and female student No. 25. The social technologies were Facebook, Whatsapp, GoogleForm, and email for FG1 and FG2 where the participants went to State Senior High School 3 Jambi City and Telegram, Edmodo, Google Form, Youtube and email for FG3 and FG4 where the participants did the teaching practicum in one state junior high school in Jambi. They were used to facilitate interactions between student teachers and lecturer/supervisors and among the participants. The activities were included reporting daily activities to the supervisors, discussing topics on teaching practicum, learning material sharing, form filling, and communication.

Table 1. The distribution of participants and focus group discussion

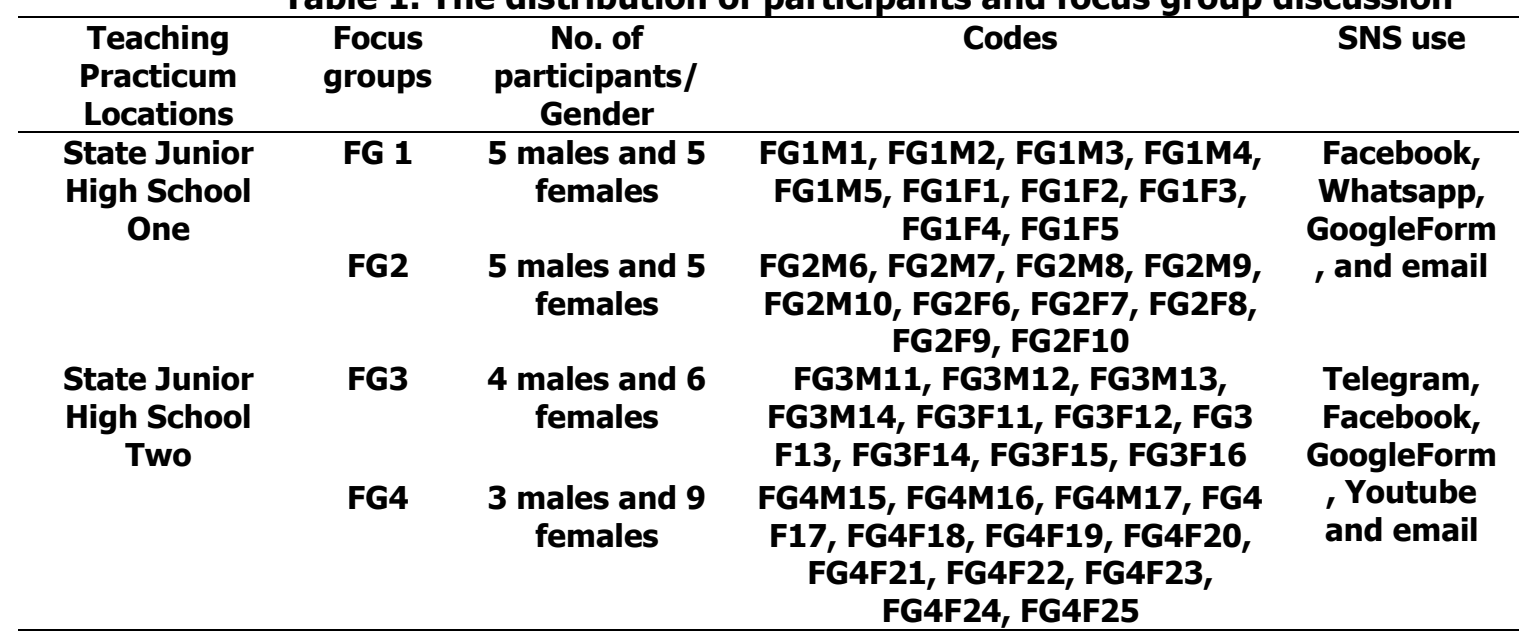


For the data analysis, the analyses across and between the data continued until no more thematic patterns were identified. Even though the participants came from different classes and with different supervisors, the data were implemented in equal manners without analyzing specific dissimilarities of how SNS were used by different groups. The analysis encompassed on identifying themes in relation to participants' experiences in using SNS. All the data transcripts were computerized, printed, read and re-read, translated, and presented. Notes were recorded in some margins to identify prospective themes. These were then collated, reviewed, and examined for connections and redundancies. The data were analyzed by manual coding thematically (Creswell, 1997, 2007; Mukminin, 2012a, 2012b, Mukminin \& McMahon, 2013). Finally, we broadened, contrasted and changed the themes concurrently with other transcript analyses. To mitigate the subjectivity bias of the research and to facilitate triangulation, the data analyses were reviewed by all researchers (Mukminin, et al., 2017a, 2017b; Sulistiyo, et al., 2017). In this study, we focused on identifying main themes that appeared when participants discussed the use of SNS for interacting with either classmates or supervisors.

\section{FINDINGS}

We organized our analysis and discussion around student teachers' perceptions and the contexts in which the advantages they perceived emerge. The analyses of the texts revealed that two salient themes with their sub-themes related to the advantages of using Social Networking Services (SNS) in a teacher education program were social interaction (peer discussion and platform to interact with supervisors or lecturers) and learning motivation and experience supports (self-directed learning, promotes critical thinking, content engagement). The following table concludes some key themes, subthemes, and explanation who commented in the focus group discussions conducted in Indonesia as the medium of instruction which were identified in the analysis. This deals with participants' perceptions on the use of social networking services (SNS) to improve their communication, supervision, discussion, and report submissions.

Table 2. Participants' perceptions on the advantages of interactions using SNS in educational activities

\begin{tabular}{|c|c|c|}
\hline Themes & Sub Themes & Explanations \\
\hline \multirow[t]{2}{*}{$\begin{array}{l}\text { Social } \\
\text { Interaction }\end{array}$} & Peer discussion & $\begin{array}{l}\text { student teachers are able to share, interact, and collaborate } \\
\text { with each other using SNS in the discussion about teaching } \\
\text { practice }\end{array}$ \\
\hline & $\begin{array}{l}\text { Platform to } \\
\text { interact with } \\
\text { supervisors or } \\
\text { lecturers }\end{array}$ & $\begin{array}{l}\text { They interact and get feedback from their lecturers using } \\
\text { SNS as platform of communication, supervision, discussion, } \\
\text { and report submission }\end{array}$ \\
\hline \multirow{3}{*}{$\begin{array}{l}\text { Learning } \\
\text { motivation } \\
\text { and } \\
\text { experience } \\
\text { supports }\end{array}$} & $\begin{array}{l}\text { Self-directed } \\
\text { learning }\end{array}$ & $\begin{array}{l}\text { student teachers are self-directed and supported by peers } \\
\text { and supervisor to discover new knowledge }\end{array}$ \\
\hline & $\begin{array}{l}\text { Promotes critical } \\
\text { thinking }\end{array}$ & $\begin{array}{l}\text { They are able to be more critical of their thought processes } \\
\text { and analytical }\end{array}$ \\
\hline & $\begin{array}{l}\text { Content } \\
\text { engagement }\end{array}$ & $\begin{array}{l}\text { They are better engaged with the program content and } \\
\text { show higher level of understanding and mastery of the } \\
\text { teaching practice }\end{array}$ \\
\hline
\end{tabular}

\section{Social Intraction}

Social interaction resulted from the peer discussion and platform to interact with supervisors or lecturers as the sub-themes. Student teachers were able to share, interact, 
and collaborate with each other using SNS in the discussion about anything in relation to the program such as teaching practices, problems, learning materials, and other things. They interacted and got feedback from their lecturers using SNS as platform of communication, supervision, discussion, and report submissions.

\section{Peer Discussion}

The phrase peer discussion points to people giving information with each other to encourage both formal learning activities - such as revising for exams - and more informal, or incidental, learning activities (Boud, Cohen, \& Sampson, 2001). Therefore, this sub-theme included all comments that participants made about sharing information with their peers to support each other's learning for the ease of the communication, supervision, discussion, and report submissions among student teachers and between supervisors and student teachers. The analysis found that all participants shared knowledge with each other when SNS was used. This resulted from sharing communication, supervision, discussion, and report submissions collected for daily, weekly, monthly, and final tasks on Whatsapp, Telegram, Google form, and email. All participants agreed on these advantages. The comments that other participants made during the process of sharing often became the sources of discussion sharing. For instance, one of the participants, FG1M1, reflected,

\section{I was online more than his friends. As a result, my friends always ask him about the supervision and communication with the supervisor. I like to comment on my friends sharing and also in email that we can discuss the final assignment.}

Some participants found this requirement to share information and comments on each other's work through email or Google Form useful for expanding their comprehension about lesson plans, learning materials or experience that they had got from the programs. For example, FG2F10 reported,

We were asked to share our opinions with our friends whenever they requested for comments in their Google Form or Wa group. Similarly, we also want the other participants to share their opinions on ours. We learn from one another. We will not know everything. Someone may have read and know more. So, SNS enable sharing to happen more often.

In general, the findings showed evidence of the greater occurrence of both off-curriculum (informal) and curriculum-based interactions in the program (teaching training/practicum) among the participants provided by SNS. The findings also indicated that participants' informal interactions such as friendly chat among friends were often converted to academic interactions where discussions revolved around the teaching topics. Further, the evidence showed that participants shared knowledge with each other using SNS. Additionally, they interacted with each other using SNS in a constructive manner, which implied that their contribution was done collaboratively and was meaningful for the other participants.

\section{Platform to Interact with Supervisors or Lecturers}

In terms of student teacher-supervisor interaction, participants generally believed that they interacted with their supervisors more frequently using SNS, compared with other forms of interaction. In most situations, participants interacted with supervisors in order to get feedback pertaining to their teaching progress and requirements. SNS interactions were particularly useful for participants when they were away for a certain period of time. Catching up with the latest development in the classroom with fellow participants and the supervisors was another way that participants used SNS. Some participants believed their interactions with supervisors increased with the use of SNS. For instance, 
Beyond class contact hours, the supervisors usually interact with us using email or Wa group and also one way communication telegram for example, the lecturer would email us on weekly basis to remind us what we should update on what we should do in our teaching. (FG4F23)

I think we have a lot less face-to-face interaction these days with our lecturer when we interact online. I mean, after the lecture, we don't go see the lecturer in person. Most of the interactions beyond class were on SNS. In my case, interacting with the lecturer is getting easier with a social technology. I interact even more with my lecturer. (FG3F15)

While face-to-face interactions were still maintained during the teaching practicum, participants considered their levels of interactions and probabilities of getting feedback from their supervisors considerably higher with the use of SNS. This indicated that the use of SNS provided an additional opportunity for participants to be in constant contacts with their supervisors regardless of time or locations. SNS basically transcended the physical boundary as well as breaks the emotional barriers that the participants might face with their supervisors in traditional modes of teaching and learning. However, it needed to be acknowledged that the use of SNS might increase workload issues for supervisors. There was a potential difficulty for supervisors in setting boundaries around their work time if participants expected to use SNS to interact with supervisors outside of work hours.

\section{Learning Motivation and Experience Supports}

Within this theme, there were three major sub-themes including self-directed monitoring learning, promoting critical thinking, and content engagement. The findings revealed that student teachers were self-directed and supported by peers and supervisors to discover new knowledge in their field. They were able to track their teaching progresses (e.g., their understanding of the lesson plans), were able to be more critical of their thought processes and analytical, and were better engaged with the program content and showed a higher level of understanding and mastery of the topics.

\section{Self-directed Monitoring Learning}

Another advantage claimed by most participants, was the convenience of having selfdirected learning enabled by the social technologies. In this context, the interaction was quite intimate between the student and the knowledge being learnt itself. Using SNS, participants on their own or together with their peers were able to discover new knowledge related to the teaching practice. In this sense, they were orchestrating their own interactions with information, teachers, and other participants in order to support their learning. Comparing SNS activities with class activities that did not involve SNS, one student considered that the use of social technology made her more independent in creating her own knowledge. In this sense, SNS generally enabled student-centered learning. With regards to this sub-theme, participants reflected, for example,

I never thought that I would need to do extra things [the use of SNS]. In this activity, we got to upload our experience in teaching, lesson plans, the story we had in the activity. It made us learn by ourselves, a very beneficial thing to do. (FG3M13)

The above statement showed that the student was relatively more self-directed and supported by peers to discover new knowledge through collaborative learning when using SNS, an observation that other participants also made. This achievement was one of the benefits that most supervisors were keen to see in their participants. However, it should be noted that participants sometimes found the expectation of self-directed learning to be "burdensome" as they were expected to invest additional time into SNS activities, which could in some instances become a barrier to participants embracing SNS in the program. 


\title{
Promoting Critical Thinking
}

SNS was very helpful for participants in developing their ability to think critically and exercise their analytical skills. Most participants said that the use of SNS enabled them to be more critical thinkers in the teaching practice. Often this was because they were expected to comment on peers' work, thus opening up the opportunity to develop critical thinking skills. For example, one of the participants, reflected,

\begin{abstract}
When someone gives comments, she wants to make the best of comments which is constructive at the same time and I do too. I actually think really carefully before I leave my comment, or before I write my blog. So in a way, I think the use of SNS actually promotes my critical thinking. It is not that I don't do that for other classes without SNS. But when we use SNS, what we write stays there online and more people are able to see it. Not just the lecturer who sees it. (FG2M2)
\end{abstract}

In situations such as the above where participants' writings were viewed in the groups, other members could also read the participants' outputs. The participants attempted to produce their best comments about the topics so that their output would be positively judged and assessed. This situation also resulted in participants become more aware and more critical in their writings.

\section{Content Engagement}

The findings of this study indicated that participants believed that they experienced greater interactions with the other participants and their lecturers when they used social technologies. They also perceived that they improved their own mastery on the course content (teaching practice) when compared to their other group without SNS use. One of the participants said,

\begin{abstract}
We have to show our level of understanding of the teaching practice meaning that we have to learn and read a lot more. After that, we need to develop the assignment with materials in our teaching that is supported by credible sources, as well as defend our arguments. We go benefits from the use of SNS. (FG1F4)
\end{abstract}

With the social media interactions, it enriches participants' own knowledge building as it promotes active and two-way communications. For example, social technology facilitated faster and more frequent interactions:

\begin{abstract}
If we communicate each other, we felt that we got engaged to make our teaching better with the use of SNS. Let say, we discussed about the topic we just taught, what I understood about it, etc. Then my friends who listened to me will add his or her perspective regarding the topic. It is not just typical feedback or discussion like "yes, I agree with you" or something like that. We sometimes discuss in detail. I realized that happened very frequent/y using SNS. (FG4M17)
\end{abstract}

From the above quotations, it can be seen that participants believed that they were better engaged with the program content and felt that they had a higher level of understanding and mastery of the topics when they were given the chance to use SNS in their supervision.

\section{DISCUSSION}

The purpose of this inquiry was to examine student teachers' perceptions on the advantages of using Social Networking Services (SNS) in an English teacher education program in Jambi, Indonesia to ease the communication, supervision, discussion, and report submissions between supervisors and student teachers. The networking types 
included in the program are Whatsapp, Telegram, Email, and Google Form. The findings of this research have provided empirical evidence on the use of Social networking Services (SNS) in education, particularly in teacher education. The findings presented here showed that student teachers recognized and valued the learning benefits of using social technologies in teacher education program, supporting earlier claims of the pedagogical rationale of the use of SNS in education (McLoughlin \& Lee, 2008; Hemmi et al., 2009; Augustsson, 2010; Hamid et al., 2015; Hadiyanto et al., 2017).

Participants tended to enjoy the use of social networking service in the program as a tool for communication, supervision, discussion, and report submission which brought interactive environment, save time, and increase motivation in the program. The benefits that student teachers informed could be grouped in two salient themes: social interaction and learning motivation and experience supporting.

As presented in the finding part, social technologies facilitated improved collaboration among student teachers anytime and anywhere. The benefits in the context of collaborative activities were revealed by all participants in this research. The use of social networking services to provide facilitations for people to interact, communicate, and collaborate in a more functional manner is in line with the pedagogical aspects of social technologies revealed in Augustsson (2010), McLoughlin and Lee (2007, 2008), Hamid et al., 2015. The results of this study are supportive the findings of a study done by Eteokleous et al., (2012) who focused on the educational role of social technologies in supporting educational activities via a formation of specific interest groups aiming to facilitate sharing, interaction sand collaboration. Another aspect of the findings showed the benefits obtained by the student teachers in terms of intensity of their relationship and communication with their supervisors or lecturers. Participants regularly interacted and communicated with their supervisors using SNS, compared with other forms of interaction. In many situations, participants interacted with supervisors in order to get feedback pertaining to their teaching progress and requirements. SNS interactions were particularly useful for participants when they were away for a certain period of time (McLoughlin \& Lee, 2008; Hemmi et al., 2009; Augustsson, 2010; Hamid et al., 2015; Habibi, 2015).

Learning motivation and experience supporting included three main sub-themes: selfdirected monitoring learning, promoting critical thinking, and content engagement. A certain benefit mentioned by most participants, was the convenience of self-directed learning that was provided by Social Networking Service (SNS). In this term, the interaction was quite intimate between the participants and the knowledge being learnt itself (Augustsson, 2010; Hamid et al., 2015). SNS was very beneficial for participants in improving their ability of critical and analytical thinking. Almost all participants stated that the use of SNS enabled them to be more critical in the teaching practice and other activities. Often this was because they were expected to comment, give suggestion, and ask questions to either their peers of supervisors. The last benefit the participants revealed was the experience on the improvement their ability and mastery on the course content which includes teaching practice. When compared to their other group without the use of SNS, it is so much better that student teachers to have SNS as a tool for communication, interaction, discussion, and report submission.

\section{CONCLUSION AND IMPLICATIONS}

The purpose of this inquiry was to examine student teachers' perceptions on the advantages of using Social Networking Services (SNS) in a teacher education program in Jambi, Indonesia to ease the communication, supervision, discussion, and report submissions between supervisors and student teachers. The networking types included in the program are Whatsapp, Telegram, Email, and Google Form. The benefits revealed in this research were in the terms of social interaction (participant to participant interaction and participant to supervisor) and learning motivation and experience supports. The findings can be used by supervisors to understand perceptions regarding the use of SNS 
and examine the use in their supervision, for the universities to set rules and guidance using SNS in their pre-service teaching training program, for student teachers to use social media to communicate each other.

The findings of this research are not readily generalizable to the context of other teaching training programs due to the use which is not yet widely used by campuses in Indonesia. Although this study was presented by rich data which in turn could provide chances for understanding the research phenomenon from a variety of other perspectives, there is an absence of statistical generalizability. A longitudinal and ethnographic study where a researcher spends a significant amount of time observing student teachers practices in interacting using SNS would be beneficial in providing richer insights about how interactions take place when they use social technologies for educational purposes. Additionally, quantitative-based research via survey with a significant number of respondents may yield different results and the findings could then be generalized to a larger population.

Furthermore, the impacts of technological changes including the use of SNS in education should be considered to improve higher education curriculum development for institutions and professional development for teaching staff (Kimmons, 2014; Merchant, 2012; Russell et al., 2014). In the context of teacher training program, the implementation of SNS must be counted to better the program in communication, supervision, discussion, and report submission. Appropriate decisions to utilize the SNS in higher educational context will result in the efficiency of time and appeal learning environment.

\section{BIODATA and CONTACT ADDRESSES of AUTHORS}

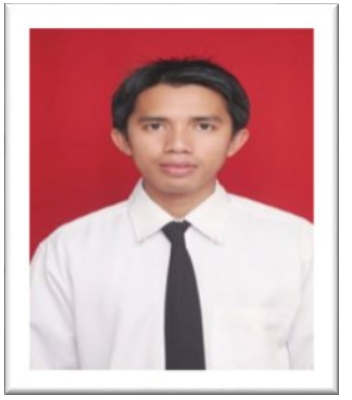

Akhmad HABIBI works as a lecturer researcher in the School of Education, Jambi University. In addition, $\mathrm{He}$ is the head of scholarship division of International Office of Jambi University. He is going to start his Ph.D. journey at the University of Malaya, Malaysia in February 2018 awarded Beasiswa LPDP, a fully-funded scholarship by Indonesian Ministry of Finance. His research interests are on the area of curriculum and instruction, educational management, and classroom management. With his colleagues, he has published his articles in some international and national journals.

\section{Akhmad HABIBI}

Faculty of Education, Jambi University

Jl. Raya Jambi-Ma. Bulian KM. 15 Mendalo Darat, Jambi, Indonesia 36361

E-mail: akhmad.habibi@unja.ac.id

Amirul MUKMININ is a faculty member at the Graduate School/Faculty of Education, Jambi University, Indonesia. He holds a PhD from Florida State University, USA in Educational Leadership and

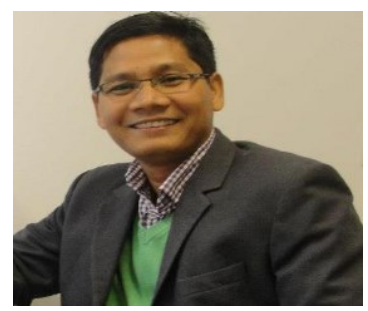
Policy Studies and MS in educational sciences from Groningen University, the Netherlands. He received a Fulbright scholarship to pursue his PhD and an Erasmus Mundus postdoctoral researcher, University of Groningen, the Netherlands. He received a 2016-2017 Fulbright Senior Research at Claremont Graduate University. His research and teaching focus on Pre-K to higher education in Indonesia and other countries. He is particularly interested in teacher policy reforms, ICT and Islamic schools and pesantren, the standardized exam policy reforms, and English/Indonesian language policy reforms which will influence educational outcomes for underachieving student populations and family. 


\section{Amirul MUKMININ}

The Graduate School/Faculty of Education, Jambi University

Address: Jl. Raya Jambi-Ma. Bulian KM. 15 Mendalo Darat, Jambi, Indonesia 36361

E-mail: amirul.mukminin@unja.ac.id

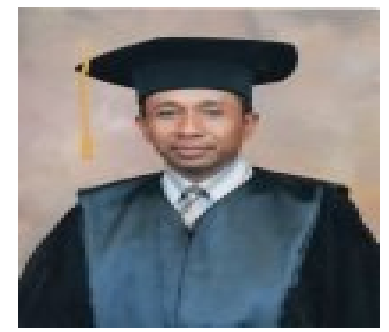

Prof. Dr. Yatim RIYANTO is a full professor at the Graduate School, Surabaya State University, Indonesia. He is particularly interested in in Educational Management and Administration, ICT and education, and teacher policy. He has published several books and research articles related to his research interest. He is also a national reviewer for national research projects.

\section{Prof. Dr. Yatim RIYANTO}

The Graduate School, Surabaya State University, Indonesia

JI. Lidah Wetan, Surabaya, Indonesia

Email: jatimriyanto@gmail.com

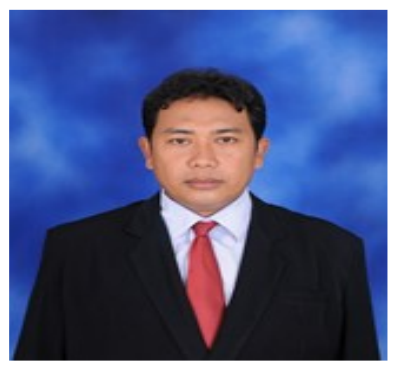

Lantip Diat PRASOJO is a faculty member at Faculty of Educational Sciences and the Graduate School, Yogyakarta State University, Indonesia. He holds a PhD from Indonesian Education University, Indonesia in Educational Management and Administration and M.Ed. in Educational Management from Yogyakarta State University. He is a national reviewers for several research projects. $\mathrm{He}$ is interested in Educational Management and Administration, ICT and education, and teacher policy. He has published several books and research articles related to his research interest.

Lantip Diat PRASOJO

The Graduate School, Yogyakarta State University, Indonesia.

Jl. Colombo No.1 Karangmalang Yogyakarta 55281

E-mail: lantip1975@gmail.com, lantip@uny.ac.id

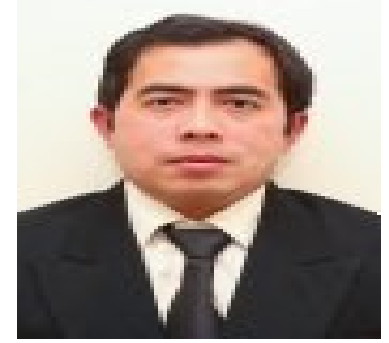

Urip SULISTIYO is a faculty member at the Graduate School/Faculty of Education, Jambi University, Indonesia. He holds a PhD in education from RMIT, Australia and M.Ed. in Education from La Trobe University, Australia. His research and teaching interests are in teacher education, ICT in education, English/Indonesian language teaching and ICT.

\section{Urip SULISTIYO}

The Graduate School/Faculty of Education, Jambi University Jl. Raya Jambi-Ma. Bulian KM. 15 Mendalo Darat, Jambi, Indonesia 36361

E-mail: urip.sulistiyo@unja.ac.id 


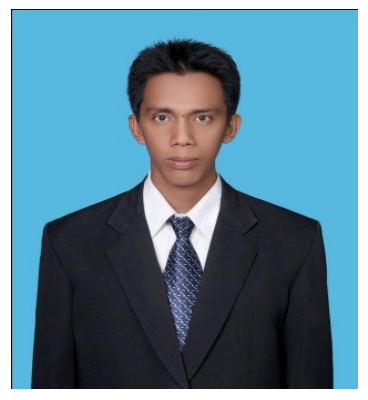

Muhammad SOFWAN is a founder of one Modern Islamic School Pesantren AIAjuharen who works as a teaching staff in Jambi University. He is active in social organizations in his city. Academically, he published his research in the area of elementary teacher education, educational management, and educational technology.

Muhammad SOFWAN

The Faculty of Education, Jambi University

JI. Raya Jambi-Ma. Bulian KM. 15 Mendalo Darat, Jambi, Indonesia 36361

E-mail: Muhammad.sofwan@unja.ac.id

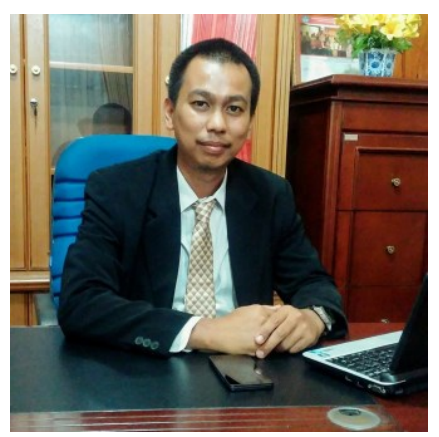

Ferdias SAUDAGAR graduated from one public university in South Sumatra, Indonesia and a teaching staff of Jambi University. He is also in charge as technology division head of Jambi University's internal control unit. His ability in the educational computer programming has made him to become a keynote speaker on some seminars or workshop. He has been trusted to manage some websites linked to Jambi University.

Ferdias SAUDAGAR

The Faculty of Education, Jambi University

JI. Raya Jambi-Ma. Bulian KM. 15 Mendalo Darat, Jambi, Indonesia 36361

E-mail: ferdias.saudagar@unja.ac.id

\section{REFERENCES}

Amador, P., \& Amador, J. (2014). Academic advising via Facebook: Examining student help seeking. The Internet and Higher Education, 21, 9-16.

Augustsson, G. (2010). Web 2.0, pedagogical support for reflexive and emotional social interaction among Swedish students. The Internet and Higher Education, 13(4), 197-205.

Boyd, D. (2007). Social network sites: Public, private, or what? Knowledge Tree, 13. Retrieved from http://www.danah.org/papers/KnowledgeTree.pdf

Brown, S. (2010). From VLEs to learning webs: The implications of Web 2.0 for learning and teaching. Interactive Learning Environments, 18(1), 1-10.

Chen, H.R., Hwang, J.P., Wu, T.T., Huang, Y.M., \& Hsueh, H.T. (2011). Assessment of implementing a digital game-based learning system over Facebook. Paper presented at the 11th IEEE International Conference on Advanced Learning Technologies, Athens, GA.

Cohen, L., Manion, L. \& Morrison, K.R.B. (2007). Research methods in education; 6th Edition. New York: Routledge.

Creswell, J. W. (2007). Qualitative inquiry and research design: Choosing among five approaches. London: Sage Publication.

Creswell, J. W. (1997). Qualitative inquiry and research design: Choosing among five approaches. London: Sage Publication. 
Eteokleous, N., Ktoridou, D., Stavrides, I., \& Michaelidis, M. (2012). Facebook - A socialnetworking tool for educational purposes: Developing special interest groups. Paper presented at the International Conference on Information Communication Technologies in Education (ICICTE), Rhodes, Greece.

Habibi (2015). Utilizing a Facebook group in teaching writing in higher intermediate classes. LIA Research Journal, 8(1), 204-211.

Hadiyanto, Mukminin, A., Failasofah, Nely, A., Fajaryani, N., \& Habibi, A. (2017). In search of quality student teachers in a digital era: Reframing the practices of soft skills in teacher education. The Turkish Online Journal of Educational Technology, 16 (3), 71-78.

Hamid, S., Kurnia, S., Waycott, J., \& Chang, S. (2011). Exploring Malaysian students' perspectives of Online Social Networking (OSN) use for higher education. Paper presented at the 22nd Annual Conference ISANA International Education Association (ISANA) 2011, Hobart, Tasmania.

Hamid, S., Kurnia, S., Waycott, J., \& Chang, S. (2015). Understanding students' perceptions of the benefits of online social networking use for teaching and learning. Internet and Higher Education, 26, 1-9.

Hemmi, A., Bayne, S., \& Land, R. (2009). The appropriation and repurposing of social technologies in higher education. Journal of Computer Assisted Learning, 25(1), 19-30.

Hosny, M.I., \& Fatima, S. (2012). Facebook in education: Students, teachers, and library perspectives. Journal of Computing, 4(6), 78-86.

Irwin, C., Ball, L., Desbrow, B., \& Leveritt, M. (2012). Students' perceptions of using Facebook as an interactive learning resource at university. Australasian Journal of Educational Technology, 28(7), 1221-1231.

Isman, A., \& Dabaj, F. (2004). Attitudes of students towards Internet. Journal of Technology and Teacher Education, 11(4), 549-577.

Johnson, B, \& Zanna, M. (1999). Attitudes: introduction and scope. In D. Albarracin, B.Johnson, \& M. Zanna (Eds.), The Handbook of attitudes (PP.3-20). New Jersey: Lawrence Erlbaum Associates.

Kane, G.C., \& Fichman, R.G. (2009). The shoemaker's children: Using wikis for Information Systems teaching, research and publication. MIS Quarterly, 33(1), 1-17.

Kimmons, R. (2014). Social networking sites, literacy, and the authentic identity problem. TechTrends, 58(2), 93-98.

Klein, H.K., Tellefsen, T., \& Herskovitz, P.J. (2007). The use of group support systems in focus group: Information technology meets qualitative research. Computers in Human Behavior, 23(5), 2113-2132.

Kuo, Y. C., Walker, A.E., Schroder, K.E.E., \& Belland, B.R. (2014). Interaction, internet selfefficacy, and self-regulated learning as predictors of student satisfaction in online education courses. The Internet and Higher Education, 20, 35-50.

Lee, S. M. (2014). The relationships between higher order thinking skills, cognitive density, and social presence in online learning. The Internet and Higher Education, 21, 41-52.

Lincoln, S. Y., \& Guba, G. E. (1985). Naturalistic inquiry. New York, NY: SAGE Publications.

Lockyer, L., \& Patterson, J. (2008). Integrating social networking technologies in education: A case study of a formal learning environment. Paper presented at the Eighth IEEE International Conference on Advanced Learning Technologies (Cantabria, Spain). 
Lowedahl, J.M. (2011). Hype cycle for higher education 2011. Gartner research report (Retrieved from http://www85.homepage.villanova.edu/timothy.ay/DIT2160/BYOD/ hype_cycle_for_education_201_214466.pdf).

Mack, N., Woodsong, C., Macqueen, M. K., Guest, G., \& Namey, M. (2005). Qualitative research method. A data collector's field guide. North Carolina: Research Triangle Park.

Markus, B (2008). E-Learning and its effects on teaching and learning in a global age : International Journal of Academic Research in Business and Social Sciences.

McLoughlin, C., \& Lee, M.J.W. (2008). The three P's of pedagogy for the networked society: Personalization, participation, and productivity. International Journal of Teaching and Learning in Higher Education, 20(1), 10-27.

Merchant, G. (2012). Unravelling the social network: Theory and research, learning. Media and Technology, 37(1), 4-19.

Merriam, S. B. (1998). Qualitative research and case study applications in education. San Francisco, CA: Jossey-Bass.

Mukminin, A., \& Mcmahon, B.J. (2013). International graduate students' cross-cultural academic engagement: stories of Indonesian doctoral students on American campus. The Qualitative Report, 18 (69), 1-19.

Mukminin, A. (2012a). From east to west: a phenomenological study of Indonesian graduate students' experiences on the acculturation process at an American public research university (Unpublished Doctoral Dissertation), the United State of America: Florida State University, the United States of America.

Mukminin, A. (2012b). Acculturative experiences among Indonesian graduate students in US higher education: academic shock, adjustment, crisis, and resolution. Excellence in Higher Education Journal, 3(1),14-36.

Mukminin, A., Rohayati, T., Putra, H. A., Habibi, A., \& Aina, M. (2017a).The long walk to quality teacher education in Indonesia: student teachers' motives to become a teacher and policy implications. Elementary Education Online, 16 (1), 35-59.

Mukminin, A., Kamil, D., Muazza, M., \& Haryanto, E. (2017b). Why teacher education? documenting undocumented female student teachers' motives in Indonesia: a case study. The Qualitative Report, 22 (1), 309-326.

Myers, M.D. (2009). Qualitative research in business and management. London: SAGE.

Osman, G., \& Koh, J.H.L. (2013). Understanding management students' reflective practice through blogging. The Internet and Higher Education, 16, 23-31.

Preece, J., \& Shneiderman, B. (2009). The Reader-to-Leader Framework: Motivating technology-mediated social participation. AIS Transactions on HumanComputerInteraction, 1(1), 13-32.

Preston, G., Phillips, R., Gosper, M., McNeill, M., Woo, K., \& Green, D. (2010). Web-based lecture technologies: Highlighting the changing nature of teaching and learning. Australasian Journal of Educational Technology, 26(6), 717-728.

Pursel, B.K., \& Xie, H. (2014). Patterns and pedagogy: Exploring student blog use in higher education. Contemporary Educational Technology, 5(2), 96-109.

Russell, C., Malfroy, J., Gosper, M., \& McKenzie, J. (2014). Using research to inform learning technology practice and policy: A qualitative analysis of student perspectives. Australian Journal of Educational Technology, 30(1), 1-15. 
Rifkin, W., Longnecker, N., Leach, J., Davis, L., \& Ortia, L. (2009). Motivate students by having them publish in new media: An invitation to Science lecturers to share and test. Paper presented at the Australian Conference on Science and Mathematics Education: Motivating Science Undergraduates - Ideas and Interventions, Sydney, Australia.

Sandars, J., \& Schroter, S. (2007). Web 2.0 technologies for undergraduate and postgraduate medical education: An online survey. Postgraduate Medical Journal, 83, 759-762.

Schroeder, A., Minocha, S., \& Schneider, C. (2010). The strengths, weaknesses, opportunities and threats of using social software in higher and further education teaching and learning. Journal of Computer Assisted Learning, 26(3), 159-174.

Shirvani, H. (2014). Do your elementary mathematics methodology class correspond to constructivist epistemology? Journal of Instructional Psychology, 36(3), 245258.

Sulistiyo, U., Mukminin, A., Abdurrahman, K., \& Haryanto, E. (2017). Learning to Teach: Indonesian EFL Student Teachers'Practicum Experience and Teacher Education Policy Recommendations. The Qualitative Report, 22(3), 712-731.

Tay, E., \& Allen, M. (2011). Designing social media into university learning: Technology of collaboration or collaboration for technology? Educational Media International, 48(3), 151-163.

Walsham, G. (2001). Making a world of difference: IT in a global context. West Sussex, UK: John Wiley \& Sons.

Wang, Q., Woo, H.L., Quek, C.L., Yang, Y., \& Liu, M. (2012). Using the Facebook group as a learning management system: An exploratory study. British Journal of Educational Technology, 43(3), 428-438.

Waycott, J., Bennett, S., Bishop, A., Dalgarno, B., \& Kennedy, G. (2012). Implementing Web 2.0 technologies in higher education: A collective case study. Computers \& Education, 59(2), 524-534.

Yu, A. Y., Tian, S. W., Vogel, D., \& Kwok, R. C. W. (2010). Can learning be virtually boosted? An investigation of online social networking impacts. Computers \& Education, 55(4), 1494-1503. 